Jurnal Pariwisata Terapan Vol. 5., No. 2, 2021

ISSN-2580-1031 (print) ISSN- 2580-104X (online)

https://jurnal.ugm.ac.id/jpt

\title{
Understanding the Multiple Factors Determining of Generation Z to Hotel Staycation During Covid-19 Pandemic
}

\author{
Septi Fahmi Choirisa1, Nosica Rizkalla²
}

\begin{abstract}
Affiliation
${ }^{1}$ Hotel Operations Program, Faculty of Business, Universitas Multimedia Nusantara

${ }^{2}$ Management Program, Faculty of Business, Universitas Multimedia Nusantara Nusantara

\section{Correspondence}

Septi Fahmi Choirisa, Hotel Operations Program, Faculty of Business, Universitas Multimedia Nusantara, St. Scientia Boulevard, Curug Sangereng, Kec. Klp. Dua, Kabupaten Tangerang, Banten 15810. Email: septi.choirisa@umn.ac.id
\end{abstract}

\begin{abstract}
The impact of the Covid-19 pandemic on restricted mobility and a devastating economic development in various sectors has changed renewed interest in the future of tourism, especially in the Hospitality Industry. This study sought to examine the Theory of Planned Behavior in the context of hotel staycation during the Covid-19 pandemic. Paired t-tests and the structural equation modelling were applied to assess the 230 responses of Generation $\mathrm{Z}$ in Indonesia for the first and second quarters of 2021. The finding showed that attitude, perceived behavioural control, and subjective norms affect the hotel staycation intention during a pandemic for $\mathbf{Z}$ generations. Perceived behavioural control plays the most significant part. Several findings are provided on how the generation perceives travelling during the COVID-19 pandemic and encourage them to resume travelling after the travel restriction is lifted. Theoretical and practical implications are discussed. The viewpoint proffered in this study provides scopes of the hospitality industry in terms of hotel staycation programs to maintain a resilient economic strategy during the pandemic.
\end{abstract}

Keywords: Hotel Staycation; Theory of Planned-Behavior; Covid-19 pandemic.

Article Information:

Submitted 24 November 2021| Revised 20 November 27 | Accepted 28 November 2021

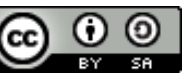

Copyright (C 2021 by the author(s). This article is published by Universitas Gadjah Mada, Indonesia under the Creative Commons Attribution (CC BY 4.0) license. Anyone may reproduce, distribute, translate, and create derivative works of this article (for both commercial and noncommercial purposes), subject to full attribution to the original publication and author(s). The full terms of this license may be seen at http://creativecommons.org/licenses/by/4.0/legalcod 


\section{Introduction}

The travel and tourism industry faced a challenging year impacting the global economic catastrophe caused by Coronavirus Disease 2019 (Covid-19) (UNWTO, 2020a). National economies, including tourism systems such as cruises, transportation, accommodation, food and beverages Industry, and events, were affected by the travel restriction in scale local, regional, and international (Gossling, 2021). The average revenue per available room (RevPar) fell nearly $90 \%$ in the second quarter of 2020 due to travel bans and tourists' fear of being stranded and is expected to continue to decline. (Courtney,2020). Many businesses almost closed or huge losses since travel consumption limitation (Wen et al., 2020). There is a risk of about 50 million jobs in travel and tourism globally, warned by The World Travel and Tourism Council (Nicola et al., 2020). Marriott International (which employs nearly 174.000 people) prepared to lay off tens of thousands of jobs on the other side in the hospitality industry. At the same time, Hilton Worldwide also told lenders on March 5, 2020, that they will be borrowing a precautionary $\% 1.75$ billion under a revolving loan to conserve cash and retain stability "because of global market instability."

Subsequently, for developing countries such as Indonesia, hotel occupancy declined in April 2020 and continued to drop until September 2020. Before September, the occupancy has seen been a steady increase since the beginning of the pandemic. It recorded the lowest performance rate of 12.67 per cent after the initial Covid-19. It then increases to 32.93 per cent in August 2020 as the highest level since the first quarter of 2020, before falling in September. The large-scale social restriction impacted this situation in several regions with border closures to prevent the virus from spreading. Indonesia was lost around seventy trillion (rupiah) was recorded by the hotel and restaurant sector based on the Indonesian Hotel and Restaurant Association (PHRI) (Parama, 2020). Throughout 2020, Statistic Indonesia (BPS) showed the occupancy rate remaining below-average level. In October 2020, the number of tourists picked up to 158.200, which increased by 4.52 per cent from September 2020. Nevertheless, it still jumped to 88.25 per cent down from the same period last year. Most provinces were primarily driven by a domestic. (Rahman, 2020). Overall, the Covid-19 crisis has thrown the hospitality Industry into disarray globally. (Nicola et al., 2020). As the spread of disease slowed, policymakers began to devise plans to reintroduce travel and re-establish economic development (Collins, 2020; Fakhruddin et al., 2020). Since the pandemic began, consumers' expectations, preferences, and attitudes toward travel have shifted (Peters et al., 2020). Consumers are more pay attention to health and infection risks recently. The hygiene issue should prioritise hotel business models to build trust concerning customer health (Deloitte, 2020). The tourism industry will undergo substantial changes in preparation for the restart, including reorganising and introducing new protocols and standards (Lew et al., 2020).

A study was conducted among the hotel industry's revenue managers, consultants, and system providers to examine the strategy implemented during the low-demands period during Covid-19. The results have shown that the domestic market is the main focus. In the short run, it became the primary market and promoted staycation packages as a flexible strategy, particularly in a pandemic. Nowadays, Staycation packages have become popular as bundling packages with rooms and other revenue centres (Guillet and Angela, 2020). Since travel restrictions appeared, many hospitality and tourism businesses had to pivot their promotion to domestic or regional market segmentation. Accommodating the issues, the Slovenia government subsidised the residents to have a staycation voucher worth 200 dollars while children were 18 years old worth 50 dollars. Approximately $15 \%$ of the hotel voucher was claimed. Most resorts are fully booked, reporting 80\%-95\% occupancy in July 2020.

In contrast, the city hotel considerably has no benefit from this scheme. The potential customer preferably spent the voucher on seaside resorts, mountain and thermal-spa accommodation that impact the forecast on the last quarter, especially in weekend season. This strategy would be quite a success for the Slovenian 
Tourism Industry (Cvelbar \& Marko, 2020). In the same vein, Singapore residents supported the staycation stimulus during the Covid-19 pandemic. More than 200 hotels got permission to offer the staycation packages. Based on STR, this program led to infinite occupancy in May, June, and July for more than $70 \%$. Several hotels were also opened for customers who need private isolation or quarantine. According to STR, more than 200 hotels had earned official approval to sell such staycation packages as of mid-August, resulting in absolute occupancy of more than $70 \%$ in May, June, and July. Many hotels have also housed returning residents who needed to be isolated and quarantined (Oh, 2020). The current study focuses on bridging the gaps by shedding light on young people's activity-travel behaviour during the Covid-19 pandemic. Based on the Theory of Planned Behaviour, the research establishes a theoretical framework to explore the relationship between attitude, perceived behaviour control, subjective norms, intention to travel for hotel staycation during a pandemic. The study provides a comprehensive view of understanding customer psychology during a pandemic. The research's fundamental questions are: (1) What factors may affect the potential customer consuming the hotel staycation during a pandemic? (2) What are the impacts of the Covid-19 pandemic to Z generations towards hotel staycation?

To mitigate the pandemic's impact, the hotel industry needs to better insight into domestic customers' psychology for young productive generations during the pandemic's devastating period. In the context of the pandemic, some hotels shifted the segmentation to broaden the market. Young people have high expectations for their travel experiences. The consumption of stay is frequently perceived as hedonistic behaviour. They often influence the family member for their destination choice (Mignon, 2003). Generations Z (Gen Z) are more likely to travel in this Covid-19 situation. According to Clarke (2018), Gen$\mathrm{Z}$ is more daring, risk-taker, and adventurous than other generations. Moreover, based on the survey conducted by Global Data, the younger traveler groups like Gen-Z are the ones who will be travelling first once the travelling restrictions are lifted (Baratti, 2020). Therefore, these results can help the hotel manager understand and carefully consider multiple factors determining the staycation. This study objective is to (1) Identify factors of domestic customers consuming the hotel staycation during pandemic using TPB and (2) examine the impact of Covid-19 pandemic to $Z$ generations towards hotel staycation. Empirically, the hotel industry's implications to develop a recovery strategy in coping with the impact of the Covid-19 pandemic. This paper's remainder is organized as follows: previous studies on the Covid-19 pandemic impact travel behaviour with various results are discussed next. The following sections are methods, including details of the quantitative research approach using the online questionnaire survey and presenting the analysis techniques. Then the findings obtained through statistical analyses are explained attached with the discussion. To sum up, the conclusions are described along with theoretical and practical contributions and limitations.

The Hospitality and Tourism Industry is one of the most rapidly growing businesses yet fragile. Some negative impacts, such as health risks, caused devastating and enduring (Rossello' et al., 2017). Although the actual economic losses from tourism-related diseases depend on their relative contributions to the national economy, travel and trade restrictions may result in significant financial losses for a country (Huang, 2009; Smith, 2006; Otoo and Kim, 2018). Related to the theory of planned behaviour, people's social behaviour is understandable. While people's beliefs may be irrational or biased, their behaviours, subjective standards, and expectations of behavioural regulation are expected to follow logically from these beliefs, resulting in a behavioural objective and, eventually, an action consistent with the overall tenor of the thoughts. Theorist argue that human action may be automatic or habitual, which contradicts this view (e.g., Aarts \& Dijksterhuis, 2000; Aarts, Verplanken, \& van Knippenberg, 1998; Bagozzi, 1981; Fazio, 1990; Ouellette \& Wood, 1998; Ronis, Yates, \& Kirscht, 1989; Triandis, 1977). The theory of planned behaviours (TPB) has been widely used to study tourists' purchasing habits (Erul et al., 2020; Park et al., 2016). 
The TPB involves attitude, perceived behaviour control (PBC), and subjective norms (SN), which explains the decision-making process which describes how decisions are made (Ajzen, 1991). The favourable or unfavourable assessment of behaviour is referred to as an attitude. Perceived behaviour control denotes a person's assessment of how difficult the behaviour is to perform. Perceived social pressure to conduct the behaviour is referred to as social norm. In this analysis, these three factors will be examined to see how they influence tourists' hotel consumption intention towards pandemic (Wang et al., 2020). According to Lin \& Chiang (2020), the research was conducted in Taiwan during a pandemic. The results found that international hotels with high facilities, products, and services have suffered in revenue compared to resorts in scenic areas. The less affected hotels were global chains. (Lin \& Chiang, 2021). In the aftermath of epidemic outbreaks, previous tourism research has concentrated mainly on the patterns of recovery (Cheer, 2020), examining how infectious diseases affect tourist arrivals and movements (Shi et al., 2020), examining how various outbreaks affect travellers' lifestyles, and expectations (Wen et al., 2020), or calculating the economic consequences. However, our understanding of the decision-making process and travel intentions in pandemic situations is still inadequate (Sandra et al., 2020). As a result, the theory of expected behaviour (TPB) helps model their behaviour in terms of travel intention during the Covid-19 scenario. However, this principle is well-known and implemented in various fields (Sandra et al., 2020).

Attitudes, Perceived Behavioral Control and Subjective Norm

According to previous research, Wen et al. (2020) found that Covid-19 temporarily affects Chinese citizens' lifestyles, travel, and Indonesian community life (Sasmita et al., 2020). Travel intention is also influenced by multiple risk factors felt by the tourist, and the perceives of safety. The risk' factors can impact the tourist anxiety in perspectives of what might happen to them while travelling (Wachyuni and Kusumaningrum, 2020). Attitude and desire are affected by tourism tendency and the trip, linked to psychological factors such as awareness and new travel attitude preferences. Hygiene, food, and accommodation all affect safety and hygiene (Riestyaningrum, Ferdaos \& Bayramov, 2020). Some researchers have looked into the impact of one's attitude toward travel intention (Jalilvand et al., 2012; Gardiner, King \& Grace, 2013; Yoon \& Uysal, 2005). According to Jalivand (2012), attitude significantly impacts travel intention, supported by Gosal et al., 2020; Amalia, 2018. Therefore, the following is the proposed hypothesis based on literature:

$\mathrm{H1}$ : Attitudes has a positive influence to travel intention during the Covid-19 pandemic

The PBC is an individual's assessment of the ease or difficulty of completing a task. The more individuals believe in the availability of resources and opportunities, the more they think they have power over their actions (Ajzen, 2005). However, despite entirely neutral attitudes and subjective norms, PBC has produced behavioural intention (Lokhorst \& Staats, 2006). Consequently, PBC is thought to increase a person's appetite and behavioural purpose (Perugini \& Bagozzi, 2001). Since the urge to perform a behaviour drives the intention to perform the behaviour (Perugini \& Bagozzi, 2001), hence this study hypothesised that:

$\mathrm{H} 2$ : Perceived behavioural control has a positive influence to travel intention during the Covid-19 pandemic

When making decisions or conducting behaviours, people follow or consider the advice of significant referents (e.g., friends, relatives, and co-workers (Meng \& Choi, 2016). Subjective norms, including attitude, indirectly affect behavioural intention through desire (Perugini \& Bagozzi, 2001). Based on a study conducted in China, the results found the attitude and subjective norm impact the hotel choice (Wang et al., 2020), which aligned with previous research of TPB (Park et al., 2016). As a result of the previous discussion, the following hypothesis is presented: 
H3: Subjective Norm has a positive influence to travel intention during the Covid-19 pandemic

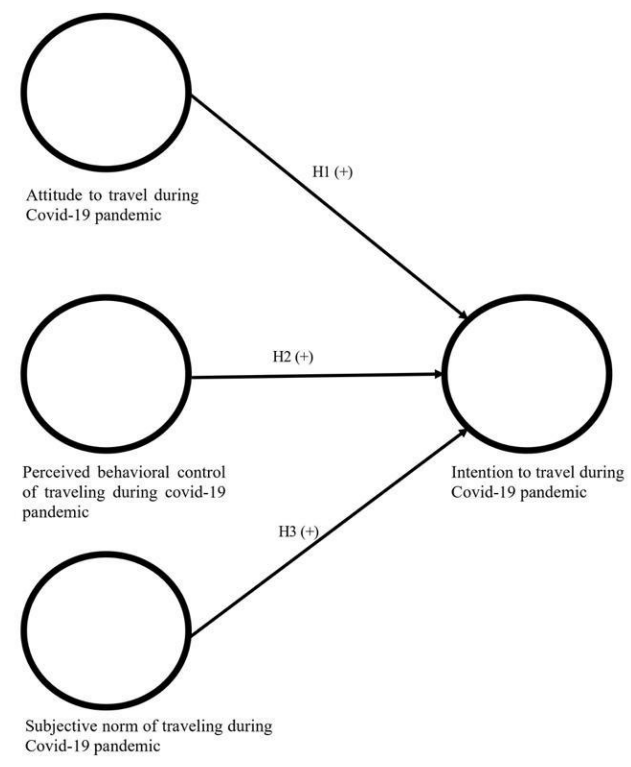

Figure no. 1: Research Framework (Theory of Planned Behavior)

\section{Methodology}

This study employed an online survey to collect the data. The total 230 respondents of this study are Gen $Z$ (Aged between 18 to 26). The respondents for this study were mainly recruited via a purposive sampling technique. Furthermore, respondents particularly are Indonesian's Gen Z who were born after 1994 (Mandelbaum, 2016). After that, prior to the main questions, to consider significant differences in hotel experiences, only respondents who answered "yes" in screening questions (i.e. have you ever experienced staying in a hotel and, or buy a staycation voucher during the pandemic?) were recruited for this study. This study used descriptive research design with a quantitative approach, as the objective of the study is to test the research hypotheses (Malhotra et al., 2017), more specifically, to test whether attitude, perceived behavioural control, and subjective norms can influence Gen Z's influence to travel during this Covid-19 situation.

Table. 1. Demographic Profile

\begin{tabular}{|l|l|l|}
\hline & Frequency & Percentage \\
\hline Gender & & \\
\hline Male & 54 & $23.5 \%$ \\
\hline Female & 170 & $73.9 \%$ \\
\hline I prefer not to say & 6 & $2.6 \%$ \\
\hline Education & & \\
\hline Secondary level or lower & 15 & $6.5 \%$ \\
\hline High School & 73 & $31.7 \%$ \\
\hline University & 142 & $61.8 \%$ \\
\hline Budget to stay & & \\
\hline Never with my budget & 8 & $3.5 \%$ \\
\hline$<$ Rp. 500.000 per night & 54 & $23.5 \%$ \\
\hline
\end{tabular}




\begin{tabular}{|l|l|l|}
\hline Rp. $500.001-$ Rp. 1000.000 per night & 117 & $50.9 \%$ \\
\hline Rp. $1000.001-$ Rp. 2000.000 per night & 41 & $17.8 \%$ \\
\hline Rp. $2000.001-$ Rp. 3000.000 per night & 8 & $3.5 \%$ \\
\hline > Rp. 3000.000 per night & 2 & $0.8 \%$ \\
\hline
\end{tabular}

As shown from Table no.1, the sample of this study is primarily female, comprising $73.9 \%$. Most of the respondents are studying (or already finishing) at the university level. Their budget to stay at the hotel during the holiday is mostly less than Rp. 500.000 per night comprises $50.9 \%$ of the total respondents. Apart from socio-demographic data, the construct items were revised from prior studies to ensure content validity. Respondents were asked by Likert Scale type, to rate the intensity of each indicator of variables on the survey ( $1=$ Strongly Disagree, $5=$ Strongly Agree). All items used in the questionnaire were adapted from previous literature, in which items for measuring attitude and subjective norms were taken from Sandra et al. (2020), items for perceived behavioural control were adopted from Bagozzi et al.(2003), and Quintal et al. (2010), and last but not least, items to measure intention to travel were adopted from Hsu and Huang (2012).

Results and Discussion

\section{Evaluation of Measurement Model (Outer Model)}

To assess the model, this study implemented the variance-based method Partial Least Square using Smart PLS 3.0, with two-stage analytical procedures (Anderson and Gerbing, 1988), consisting of evaluating the outer or measurement model and inner or structural model. The evaluation of the measurement model in the first stage consists of reliability, convergent validity, and discriminant validity. To evaluate the convergent validity, this study assesses the score of outer loadings of each indicator as well as the score of average variances extracted (AVE).

Table. 2. Summary of Convergent Validity and Reliability

\begin{tabular}{|l|l|l|l|l|}
\hline Variables & $\begin{array}{l}\text { No } \\
\text { Indicators }\end{array}$ & $\begin{array}{l}\text { Cronbach's } \\
\text { Alpha }\end{array}$ & CR & AVE \\
\hline Attitude & 3 & 0.720 & 0.840 & 0.638 \\
\hline Perceived Behavioral Control & 4 & 0.806 & 0.869 & 0.625 \\
\hline Subjective Norm & 4 & 0.843 & 0.889 & 0.667 \\
\hline Intention to Travel & 3 & 0.856 & 0.913 & 0.777 \\
\hline
\end{tabular}

This study used 2 (two) criteria to assess reliability, which is composite reliability and Cronbach's alpha, in which the score for these two criteria has to be above 0.7. As presented in table no.2, all variables used in this model are reliable because the scores have exceeded the minimum threshold of 0.7. All items used in the questionnaire were adapted from previous literature, in which items for measuring attitude and subjective norms were taken from Sandra et al. (2020), items for perceived behavioural control were adopted from Bagozzi et al.(2003), and Quintal et al. (2010), and last but not least, items to measure intention to travel were adopted from Hsu and Huang (2012). The detail of items used in this study can be seen in Table no. 3 below: 
Table. 3. Research Instruments

\begin{tabular}{|c|c|c|c|}
\hline Variables & Code & Items & $\begin{array}{l}\text { Outer } \\
\text { Loadings }\end{array}$ \\
\hline \multirow{3}{*}{ Attitude } & ATT1 & $\begin{array}{l}\text { In the current situation, it would be nice to have a } \\
\text { staycation at the hotel in short/medium term }\end{array}$ & 0.778 \\
\hline & ATT2 & $\begin{array}{l}\text { In the current situation, it would be fun to staycation at } \\
\text { the hotel in short/medium term }\end{array}$ & 0.881 \\
\hline & ATT3 & $\begin{array}{l}\text { "In the current situation, staycations at the hotel in } \\
\text { short/medium term would be }\end{array}$ & 0.731 \\
\hline \multirow{4}{*}{$\begin{array}{l}\text { Perceived } \\
\text { Behavioural } \\
\text { Control }\end{array}$} & PBC1 & $\begin{array}{l}\text { Whether or not to staycation at the hotel in the current } \\
\text { situation is entirely up to me }\end{array}$ & 0.718 \\
\hline & PBC2 & $\begin{array}{l}\text { I have the necessary resources to have a staycation at the } \\
\text { hotel in the current situation }\end{array}$ & 0.764 \\
\hline & PBC3 & My freedom to have a staycation at the hotel is high & 0.851 \\
\hline & PBC4 & For me, to have a staycation at the hotel is easy & 0.821 \\
\hline \multirow{4}{*}{$\begin{array}{l}\text { Subjective } \\
\text { Norms }\end{array}$} & SN1 & $\begin{array}{l}\text { I would be influenced by my family's opinion when } \\
\text { deciding to staycation at the hotel in the current situation }\end{array}$ & 0.776 \\
\hline & SN2 & $\begin{array}{l}\text { I would be influenced by my friends'/colleagues' opinions } \\
\text { when making the decision to staycation at the hotel in the } \\
\text { current situation }\end{array}$ & 0.774 \\
\hline & SN3 & $\begin{array}{l}\text { Most people who are important to me would support my } \\
\text { staycation planning in the current situation }\end{array}$ & 0.866 \\
\hline & SN4 & $\begin{array}{l}\text { Most people who are important to me think I should have } \\
\text { a staycation planning in the current situation }\end{array}$ & 0.845 \\
\hline \multirow{3}{*}{$\begin{array}{l}\text { Intention to } \\
\text { Travel }\end{array}$} & INT1 & I intend to have a staycation at the hotel as soon as I can & 0.891 \\
\hline & INT2 & $\begin{array}{l}\text { I need to have a staycation at the hotel for work in the } \\
\text { short/medium term. I intend to do so }\end{array}$ & 0.869 \\
\hline & INT3 & $\begin{array}{l}\text { I need to have a staycation for leisure in short/medium } \\
\text { term. I intend to do so }\end{array}$ & 0.884 \\
\hline
\end{tabular}

Next, convergent validity was evaluated by assessing the Average Variance Extracted (AVE) and outer loadings of each indicator. Based on the result, AVE for each variable is above the minimum requirement of 0.5. Additionally, as presented in table 4.2, the outer loadings of each indicator are also above 0.7, which is the minimum requirement for the loadings. Based on these criteria, it can be concluded that the convergent validity has been fulfilled.

Table. 4. Discriminant Validity

\begin{tabular}{|l|l|l|l|l|}
\hline Fornell-Larcker Criterion & ATT & INT & PBC & SN \\
\hline Attitude (ATT) & 0.799 & & & \\
\hline Intention to Travel (INT) & 0.321 & 0.881 & & \\
\hline Perceived-Behavioral Control (PBC) & 0.323 & 0.490 & 0.790 & \\
\hline Subjective Norms (SN) & 0.325 & 0.372 & 0.430 & 0.817 \\
\hline
\end{tabular}


After evaluating the convergent validity and reliability, this study also evaluating discriminant validity by assessing the comparison of the loadings of each item with the total cross-loadings, in which the loadings of each item should be higher than the cross-loadings from the other construct. The discriminant validity is also determined by assessing the Fornell-Larcker criterion in which the AVE of each construct should be bigger than the squared correlation with another construct (Hair et al., 2013). As can be seen in Table no.4 and Table no.5, all requirements for discriminant validity are also fulfilled.

Table. 5. Cross-Loadings

\begin{tabular}{|c|c|c|c|c|}
\hline & ATTITUDE & INTENTION TO TRAVEL & $\begin{array}{c}\text { PRCVD.BEHAVIORAL } \\
\text { CONTROL }\end{array}$ & $\begin{array}{c}\text { SUBJECTIVE } \\
\text { NORMS }\end{array}$ \\
\hline ATT1 & 0.778 & 0.191 & 0.19 & 0.147 \\
\hline ATT2 & 0.881 & 0.321 & 0.363 & 0.34 \\
\hline ATT3 & 0.731 & 0.231 & 0.178 & 0.249 \\
\hline INT1 & 0.236 & 0.891 & 0.457 & 0.308 \\
\hline INT2 & 0.286 & 0.869 & 0.372 & 0.361 \\
\hline INT3 & 0.325 & 0.884 & 0.462 & 0.317 \\
\hline PBC1 & 0.273 & 0.221 & 0.718 & 0.368 \\
\hline PBC2 & 0.308 & 0.316 & 0.764 & 0.392 \\
\hline PBC3 & 0.258 & 0.434 & 0.851 & 0.392 \\
\hline PBC4 & 0.223 & 0.486 & 0.821 & 0.261 \\
\hline SN1 & 0.216 & 0.188 & 0.215 & 0.776 \\
\hline SN2 & 0.2 & 0.222 & 0.226 & 0.774 \\
\hline SN3 & 0.311 & 0.394 & 0.495 & 0.866 \\
\hline SN4 & 0.294 & 0.331 & 0.355 & 0.845 \\
\hline
\end{tabular}

4.2 Evaluation of Structural Model (Inner Model)

This study conducted bootstrapping method with 5000 resamples to test the significance of each path coefficient as well as to test the research hypotheses (Hair et al., 2016). Standardized coefficient estimates indicated that the path between attitude and intention to travel $(\beta=1.48 ; p<0.05)$ between perceived behavioral control intention to travel $(\beta=3.72 ; p<0.05)$ as well as between subjective norms and intention to travel $(\beta=1.64 ; p<0.01$ ) were all significant and positive, which supported the hypotheses proposed in this study. The detail of this analysis is presented on Table no. 6 and Figure 2 below: 


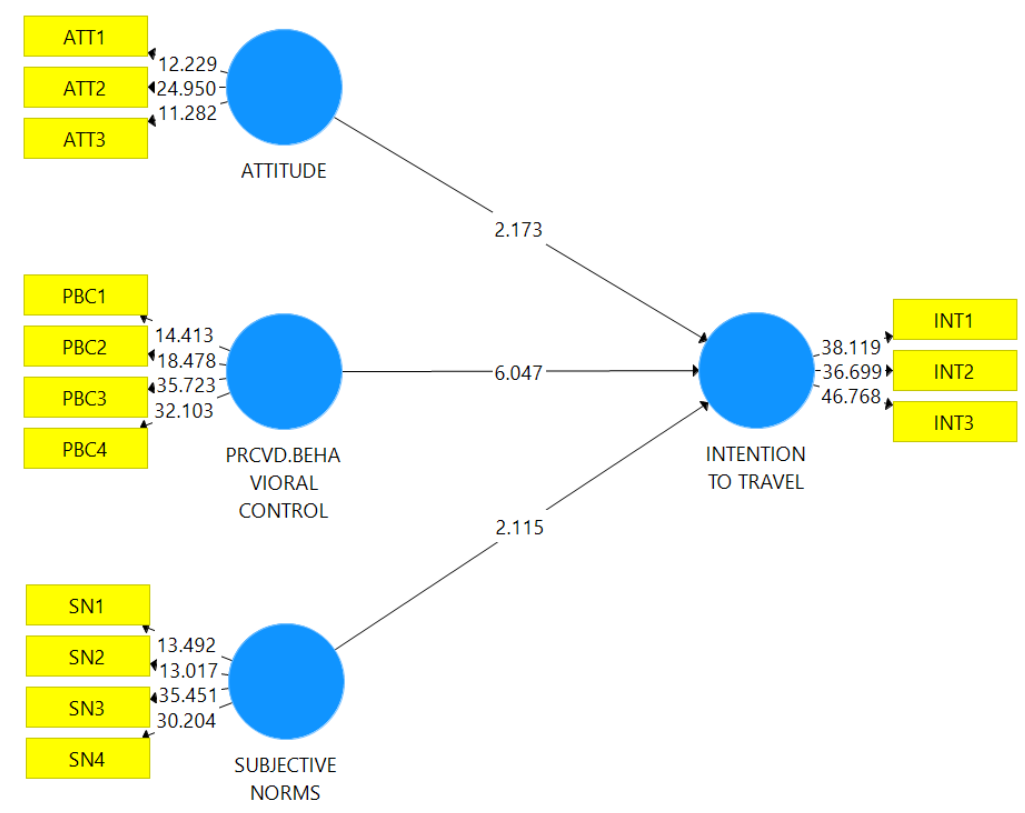

Figure 4.1. Structural Model Source: Author

Based on the analysis of data, the explanatory power of the model used to explain intention to travel reached $28.2 \%$. This implies that $28.2 \%$ of the variation of intention to travel during Covid-19 can be explained by the theory of planned behaviour, which consists of attitude, perceived behavioural control, and subjective norms. As for the remaining $71,8 \%$, it is accounted to the external factors that were not included in the model.

Table. 6. Path Coefficients

\begin{tabular}{|l|l|l|l|l|l|l|l|}
\hline & Path & Beta & t-value & p-value & Decision & Adj R2 & f2 \\
\hline H1 & ATT > INT & 0.148 & 2.173 & $0.030^{*}$ & Accept & 0.282 & 0.026 \\
\hline H2 & PBC > INT & 0.372 & 6.047 & $0.000^{* *}$ & Accept & & 0.152 \\
\cline { 1 - 5 } H3 & SN > INT & 0.164 & 2.115 & $0.034^{*}$ & Accept & & 0.030 \\
\hline
\end{tabular}

* denote significance at the $5 \%$ levels, ${ }^{* *}$ denote significance at the $1 \%$ levels

As can be concluded by the result, the factor that contributes the most to the intention to travel is perceived behavioural control, reflected by its beta score, which is higher than the beta of two other factors. This result shows a similar pattern with the research from Martin et al. in 2011, which found that perceived behavioural control to be one of the most important factors in the formation of travel intention (Martin et al., 2011). Perceived behavioural control, in general, portrays the confidence of an individual in performing a certain behaviour (Bandura, 1982). If this behaviour is perceived to be too difficult to commence, or if an individual feel that the barrier to perform the aforementioned behaviour is too many, then this will hinder them from performing the behaviour (Jalilvand and Samiei, 2016). In the context of travelling, perceived behavioural control could be related to the choice of destination or the choice of whether to travel or not. In this study, the context of behavioural control is more on the decision of whether to have a hotel staycation or not during this covid-19 situation. The result shows that if individuals feel confident in their ability to travel during this pandemic era, then the likelihood of their staycation is 
higher. Moreover, if the individuals feel that the barrier of travelling in this Covid-19 is not too lifethreatening or can be handled, then this will also increase their likelihood to staycation in. In this sense, if the hotel management wants to resume their business after the travel restriction is lifted, they have to ensure that the traveller has enough self-confidence to travel. They also have to ensure that perceived barriers that can hinder the consumer from travelling are organized well or even reduced. This can be done by making sure that the hotel management has complied with all the health protocols, like the restriction of a maximum number of visitors, the availability of sanitation facilities, and so on. In addition, the hotel management can also apply for the additional safety or cleanliness certification to further ensure the traveller that their place is secure and safe.

The second factor that can also influence intention to travel is attitude. This result is in line with the result of Hsu (2013), which postulated that attitude plays an important role in determining the intention to visit a recreation spot. If the individuals perceive a specific behaviour to be positive and favourable, then the likelihood of them conducting this behaviour will be more significant (Zhang et al., 2020). In the context of this study, if the individuals view that hotel staycation during the Covid-19 situation after the travel restriction is lifted as something safe and positive, then there is a big chance that they would do it. Therefore, it is essential for the hotel management to build a positive image of their own place to show that it is entirely safe and secure for the consumer to visit. This positive image can be made by installing a proper health protocol or educating the staff about the health protocol. Then it is essential to publicize or communicate all the efforts that have been taken to consumers so that they know that the place is entirely safe. Suppose the consumers understand and acknowledge that the hotel management has taken a proper procedure. In that case, this will make them form a more positive attitude about the hotel, encouraging them to visit the aforementioned destination. The last factor of the proposed model is subjective norms, which are also significant in influencing intention to travel. The ability of subjective norms to influence intention has been acknowledged in many contexts in marketing, including in tourism (Quintal et al., 2015). According to Abassi et al. (2019), the decision to visit a hotel is heavily influenced by individuals' views about whether their decision will be approved by their significant others, like family or friends. Especially in the Covid-19 situation, the decision to travel is no longer based on one's desire but depends on the approval of the individual's surroundings. This result can give insight for the hotel management about the importance of subjective norms in their effort in resuming the business. Hotel management can make use of the subjective norms in the designation of their marketing and promotional campaign. For example, in making advertisements (safe for the family, fun for the family) or the designation of sales promotion (package deals, referral code, etc.).

\section{Conclusions}

Travel behaviours are significantly different during pandemic situations than typical (pre-pandemic) situations, owing to government restrictions and individual fear of infection. This study presented the results of a quantitative survey of young generations to examine the changes in staycation intention due to the ongoing situation. Answering the first research questions, the attitude perceived behavioural control, and subjective norms are multiple factors determining the $Z$ generations to have a hotel staycation during the Covid-19 pandemic. The findings also explained that the second question of this study refers to impacts. The $Z$ generations are more likely to deal with the effects of Covid-19 if the hotel management applies an established health protocol and declares the hygiene focus with certification. There are certain limitations to this study. The respondents are $Z$ generations which may limit the generalizability of the findings. Given the difficulty of the theoretical model, future research might use a mixed-methods approach or qualitative analysis to improve the framework's explanations (KhooLattimore, Mura, \& Yung, 2019). Subsequently, further research could consider the extensive variable for 
supporting the intention to visit, such as travel risk, people cultural values (e.g., collectivism vs individualism) (e.g., Wen, Huang, \& Ying, 2019). More research into the relationships between "travel fear" and changes in actual travel behaviour is needed (e.g., Viglia \& Dolnicar, 2020).

This study implies for theoretical. Initially, this study contributed to developing the Theory of Planned Behaviour in the current generation's decision-making process. A comprehensive understanding of how hospitality customers view health risks and how this affects their decisions to visit hotels is still required (Williams and Balaz, 2015). This study fills the gap by identifying the impact of the Covid-19 pandemic that could affect the current generation perceived. Understanding the consumer phenomenon during a pandemic can offer insight for hotel management, especially for a person who plays a dominant role to boost their strategy in running the business during the suffering period. Mainly, the hotel management could provide more information on planning and taking action in the study to prevent Covid-19. Furthermore, authorities can create emotional appeals to positively reframe COVID-19 or increase public acceptance of COVID-19's reality.

\section{References}

Aarts, H., \& Dijksterhuis, A. (2000). Habits as knowledge structures: Automaticity in goal-directed behaviour. Journal of Personality and Social Psychology, 78, 53-63.

Aarts, H., Verplanken, B., \& van Knippenberg, A. (1998). Predicting behavior from actions in the past: Repeated decision making or a matter of habit? Journal of Applied Social Psychology, 28, 13551374.

Abbasi, G. A., Kumaravelu, J., Goh, Y. N., \& Singh, K. S. D. (2021). Understanding the intention to revisit a destination by expanding the theory of planned behaviour (TPB). Spanish Journal of MarketingESIC.

Ajzen I. (2005). Attitudes, personality and behavior. Second edition. Berkshire : McGraw-Hill Education (UK).

Anderson, J. C., \& Gerbing, D. W. (1988). Structural equation modeling in practice: A review and recommended two-step approach. Psychological Bulletin, 103(3), 411

Bagozzi, R. P. (1981). Attitudes, intentions, and behavior: A test of some key hypotheses. Journal of Personality and Social Psychology, 41, pp.607-627.

Bagozzi, R., Dholakia, U. M., \& Basuroy, S. (2003). How effortful decisions get enacted: The motivating role of decision processes, desires, and anticipated emotions. Journal of Behavioral Decision Making, 16(4), 273-295. https://doi.org/10.1002/bdm.446

Bandura, A. (1982). Self-efficacy mechanism in human agency. American psychologist, 37(2), 122.

Baratti, L. (2020). "Gen Z and Millennials Are Key to Travel Industry's Recovery". Travel Pulse. Available at https://www.travelpulse.com/news/features/gen-z-and-millennials-are-key-to-travel-industrysrecovery.html <accessed on 11 May 2021>

Brewer, N. T., \& Fazekas, K. I. (2007). Predictors of HPV vaccine acceptability: A theory-informed, systematic review.

Brewer, N. T., Chapman, G. B., Gibbons, F. X., Gerrard, M., McCaul, K. D., \& Weinstein, N. D. (2007). Metaanalysis of the relationship between risk perception and health behavior: The example of vaccination. Health Psychology, 26(2), 136-145. https://doi.org/10.1037/0278-6133.26.2.136

Clarke, R., (2018). “Generation Z Are Risk Takers - But Business Leaders Mustn't Ignore Them”. HR Review. Available at https://www.hrreview.co.uk/hr-news/strategy-news/generation-z-are-risk-takersbut-business-leaders-mustnt-ignore-them/113200 <accessed on 11 May 2021>

Collins, S. (2020). COVID-19 recovery in the UK - The importance of domestic demand. HVS. https://www.hvs.com/ article/8787-covid-19-recovery-in-the-UK-the-importance-of-domesticdemand 
Courtney, J. (2020). COVID-19 Will Cause a Significant Decline in Global RevPAR, Cash Flow, for Rated Lodging Companies. Spglobal. URL www.spglobal. com/ratings/en/research/articles/200311covid-19-w illcause-a-significant-decline-in-global-revpar-cash-flow -for-rated-lodgingcompanies-11382396\#ID493 (accessed 29 0ctober 2020).

Deloitte. (2020). "Impact of the COVID-19 crisis on short- and medium-term consumer behavior: will the COVID-19 crisis have a lasting effect on consumption?", available at: www2.deloitte.com/content/dam/Deloitte/de/Documents/consumerbusiness/Impact\%20of\%2 0the\%20COVID19\%20crisis\%20on\%20consumer\%20behavior.pdf. [cited 2020 Mar 20].

Fakhruddin, B., Blanchard, K., \& Ragupathy, D. (2020). Are we there yet? The transition from response to recovery for the COVID-19 pandemic. Progress in Disaster Science, 7, 100102. https://doi.org/10.1016/j.pdisas.2020.100102

Fazio, R. H. (1990). Multiple processes by which attitudes guide behavior: The MODE model as an integrative framework. In M. P. Zanna (Ed.), Advances in experimental social psychology (Vol. 23, pp. 75-109). San Diego, CA: Academic.

Febriana Riestyaningrum, Ehsan Ferdaos, Bahruz Bayramov. (2020). Customer behavior impact on international tourist's travel intention due to Covid-19, Journal of Sustainable Tourism and Entrepreneurship (JoSTE) ISSN: 2714-6480, Vol 1, No 3, 2020, 231-243 https://doi.org/10.35912/joste.v1i3.367

Gardiner, S., King, C., \& Grace, D. (2013). Travel decision making an empirical examination of generational values, attitudes, and intentions. Journal of Travel Research, 52(3), 310-324.

Gosal, J., Andajani. E, \& Rahayu. S. (2020). The effect of e-wom on travel intention, travel decision, city image, and attitude to visit a tourism city. Advances in Economics, Business and Management Research, 115, 261-265

Guillet, Basak Denizci and Angela Mai Chi Chu. (2020). Managing hotel revenue amid the COVID-19 crisis. International Journal of Contemporary Hospitality Management Vol. 33 No. 2, 2021 pp. 604-627. Emerald Publishing Limited 0959-6119. DOI 10.1108/IJCHM-06-2020-0623

Hair, J. F., Ringle, C. M., \& Sarstedt, M. (2013). Partial least squares structural equation modeling: Rigorous applications, better results and higher acceptance. Long Range Planning, 46(1-2), 1-12.

Hotels Chains Maneuver to Deal with Coronavirus Gut Punch, Skift. (2020). Available from: https://skift.com/2020/03/18/hotelschains-maneuver-to-deal-with-coronavirus-gut-punch/ \& Tourism Research, 36(3), 390-417. https://doi.org/10.1177/1096348010390817. [cited March 2021].

Hsu, C. H. C., \& Huang, S. (2012). An extension of the theory of planned behavior model for tourists. Journal of Hospitality \& Tourism Research, 36(3), 390-417. https://doi.org/10.1177/1096348010390817

Hsu, M. C. (2013). The management of sports tourism: A causal modeling test of the theory of planned behaviour. International Journal of Management, 30(2), 474.

Huang, Y. (2009). In-flew-Enza: pandemic influenza and its security implications. Innovation in Global Health Governance: Critical Cases. Ashgate Publishing, pp. 129-152.

Jalilvand, M.R., Samiei, N., Dini, B., Manzari, P.Y. (2012). Examining the structural relationships of electronic word of mouth, destination image, tourist attitude toward destination and travel intention: An integrated approach. Journal of Destination Marketing \& Management, 1(2) 134143.

Khoo-Lattimore, C., Mura, P., \& Yung, R. (2019). The time has come: A systematic literature review of mixed methods research in tourism. Current Issues in Tourism, 22 (13), 1531-1550.

Knežević Cvelbar L and Ogorevc M. (2020). Saving the tourism industry with staycation vouchers [version 1; peer review: 2 approved, 1 approved with reservations]. Emerald Open Res 2020, 2:65 (https://doi.org/10.35241/emeraldopenres.13924.1) 
Lew, A., Cheer, J. M., Haywood, M., Brouder, P., \& Salazar, N. B. (2020). Visions of travel and tourism after the global COVID-19 transformation of 2020. Tourism Geographies, 22(3), 455-466. https://doi.org/10.1080/14616688.2020.1770326

Lokhorst, A. M., \& Staats, H. (2006). Understanding farmers'intentions to carry out agricultural nature management: Using an adapted EMGB. Leiden University.

Malhotra, N. K., Nunan, D., \& Birks, D. F. (2017). Marketing research: An applied approach. Pearson Education Limited.

Mandelbaum, A. (2016). What Should Your Hotel Know About Generation Z? [Online] Available at: https://lodgingmagazine.com/what-should-your-hotel-know-about-generation-z/

Martin, D. S., Ramamonjiarivelo, Z., \& Martin, W. S. (2011). MEDTOUR: a scale for measuring medical tourism intentions. Tourism Review.

McKercher, B., \& Chon, K. (2004). The over-reaction to SARS and the collapse of Asian tourism. Annals of Tourism Research, 31(3), 716-719. https://doi.org/10.1016/j.annals.2003.11.002

Mengqing Wang, Ziming Jin, Sijing Fan, Xiaoxi Ju \& Xiao Xiao. (2021). Chinese residents' preferences and consuming intentions for hotels after COVID-19 pandemic: a theory of planned behaviour approach, Anatolia, 32:1, 132-135, DOI: 10.1080/13032917.2020.1795894

Mignon, J.-M. (2003), "Le tourisme des jeunes. Une valeur sûre", dans Cahier Espaces, No. 77.

Nicola, Maria, Zaid Alsafib, Catrin Sohrabic, Ahmed Kerwand, Ahmed Al-Jabird, Christos losifidisc, Maliha Aghae, Riaz Aghaf. (2020). The socio-economic implications of the coronavirus pandemic (COVID19): A review, International Journal of Surgery Volume 78, June 2020, Pages 185-193, https://doi.org/10.1016/j.ijsu.2020.04.018

Ochega A. Ataguba \& John E. Ataguba. (2020). Social determinants of health: the role of effective communication in the COVID-19 pandemic in developing countries, Global Health Action, 13:1, 1788263, DOI: 10.1080/16549716.2020.1788263

Oh, Selena. (2020). Singapore helps hoteliers with staycation stimulus, URL: https://vtechworks.lib.vt.edu/bitstream/handle/10919/99976/1.\%20Singapore\%20helps\%20hot eliers\%20with\%20staycation\%20stimulus.pdf?sequence=1\&isAllowed=y (accessed 15 March 2021)

Otoo, F., Kim, S. (2018). Is there stability underneath health risk resilience in Hong Kong inbound tourism? Asia Pacific J. Tour. Res. 23 (4), 344-358.

Ouellette, J. A., \& Wood, W. (1998). Habit and intention in everyday life: The multiple processes by which past behavior predicts future behavior. Psychological Bulletin, 124, 54-74.

Parama, Mardika. (2020). Hotel occupancy rate drops slightly in September after rally. The Jakarta Post. Retrieved from thejakartapost.com with the title "Foreign tourist arrivals, hotel occupancy rate yet to recover in October:

read: https://www.thejakartapost.com/news/2020/12/02/foreign-tourist-arrivals-hoteloccupancy-rate-yet-to-recover-in-october-bps.html. [cited March 21].

Park, S., Hsieh, C., \& Lee, C. (2016). Examining Chinese college students' intention to travel to Japan using the extended theory of planned behavior: Testing destination image and the mediating role of travel constraints. Journal of Travel \& Tourism Marketing, 34(1), 113-131. https://doi.org/10.1080/10548408.2016.1141154

Perugini, M., \& Bagozzi, R. (2001). The role of desires and anticipated emotions in goal-directed behaviors: Broadening and deepening the theory of planned behavior. British Journal of Social Psychology, 40(1), 79-98. https://doi.org/10.1348/014466601164704

Peters, K., Peters, J., \& Peters, N. (2020). Visit people Tourism Recovery. KPPM Strategy. Retrieved from: http://kppm.com.au/wp-content/uploads/2020/04/KPPM-Tourism-Recovery-Lit-Review-4-420.pdf 
Quintal, V. A., Lee, J. A., \& Soutar, G. N. (2010). Risk, uncertainty and the theory of planned behavior: A tourism example. Tourism Management, 31(6), 797-805. https://doi.org/10.1016/j.tourman.2009.08.006

Quintal, V. A., Thomas, B., \& Phau, I. (2015). Incorporating the winescape into the theory of planned behavior: Examining' new world'wineries. Tourism Management, 46, 596-609.

Reisinger Y, Mavondo F. (2005). Travel Anxiety and Intentions to Travel Internationally: Implications of Travel Risk Perception. Journal of Travel Research : 43(3):212-225. doi:10.1177/0047287504272017

Reza Jalilvand, M., \& Samiei, N. (2012). The impact of electronic word of mouth on a tourism destination choice. Internet Research, 22(5), 591-612.

Richter, L. (2003). International tourism and its global health consequences. Journal of Travel Research, 41(4), 340-347. https://doi.org/10.1177/0047287503041004002

Ronis, D. L., Yates, J. F., \& Kirscht, J. P. (1989). Attitudes, decisions, and habits as determinants of repeated behavior. In A. R. Pratkanis, S. J. Breckler, \& A. G. Greenwald (Eds.), Attitude structure and function (pp. 213-239). Hillsdale, NJ: Lawrence Erlbaum Associates, Inc.

Rossello', J., Santana-Gallego, M., Awan, W. (2017). Infectious disease risk and international tourism demand. Health Policy Plan. 32 (4), 538-548.

Sandra M. Sánchez-Cañizares, L. Javier Cabeza-Ramírez, Guzmán Muñoz-Fernández \& Fernando J. Fuentes-García. (2020). Impact of the perceived risk from Covid-19 on intention to travel, Current Issues in Tourism, DOI: 10.1080/13683500.2020.1829571

Sasmita, N., Komara, L.L., Purba, J.H., Pandawani, N.P. (2020). The Impact of Covid-19 on community life in the province of Bali, Indonesia. International Journal of Psychosocial Rehabilitation, 24(10):1918-1929.

Smith, R.D. (2006). Responding to global infectious disease outbreaks: lessons from SARS on the role of risk perception, communication, and management. Soc. Sci. Med. 63 (12), 3113-3123.

Sönmez, S. F. (1998). Tourism, terrorism, and political instability. Annals of Tourism Research, 25(2), 416456. https://doi. org/10.1016/S0160-7383(97)00093-5

Sönmez, S. F., \& Graefe, A. R. (1998a). Influence of terrorism risk on foreign tourism decisions. Annals of Tourism Research, 25(1), 112-144. https://doi.org/10.1016/S0160-7383(97)00072-8

Stefan Gössling, Daniel Scott \& C. Michael Hall. (2021). Pandemics, tourism and global change: a rapid assessment of COVID-19, Journal of Sustainable Tourism, 29:1, 120, DOI: $10.1080 / 09669582.2020 .1758708$

USAToday. (2020). Marriott furloughs tens of thousands of employees due to coronavirus. Available from: https://www.usatoday.com/story/money/2020/03/17/marriott-furloughs-layoffs-coronaviruscovid-19/5068070002/. [cited 2020 Mar 20].

Viglia, Giampaolo \& Dolnicar, Sara. (2020). A review of experiments in tourism and hospitality. Annals of Tourism Research. 80. 102858. 10.1016/j.annals.2020.102858.

Wen, J., Huang, S. S., \& Ying, T., (2019). Relationships between Chinese cultural values and tourist motivations: A study of Chinese tourists visiting Israel. Journal of Destination Marketing \& Management, 14, 100367.

Wen, J., Kozak, M., Yang, S., \& Liu, F., (2020). COVID-19: Potential effects on Chinese citizens' lifestyle and travel. Tourism Review(). Advance online publication. https://doi.org/10.1108/TR-03-2020-0110.

World Economic Forum. (2020). Available from: https://www. weforum.org/agenda/2020/03/worldtravel-coronavirus-covid19-jobs-pandemictourism-aviation/. [cited 2020 March 20

Yoon, Y., \&Uysal, M. (2005). An examination of the effects of motivation and satisfaction on destination loyalty: a structural model. Tourism Management, 26(1), 45-56. 
Yu-Chen Lin \& Chiang-Ming Chen.(2021). How do hotel characteristics moderate the impact of COVID-19 on hotel performance? Evidence from Taiwan, Current Issues in Tourism, DOI: $10.1080 / 13683500.2021 .1910213$

Zhang, G., Chen, X., Law, R., \& Zhang, M., (2020). Sustainability of Heritage Tourism: A Structural Perspective from Cultural Identity and Consumption Intention. Sustainability, 12(21), 9199. 